ISSN 2076-0752

www.mdpi.com/journal/arts

Article

\title{
Hand Traces: Technical Aspects of Positive and Negative Hand-Marking in Rock Art
}

\section{Patricia Dobrez}

Independent scholar, 9 Blair Street, Watson, Australian Capital Territory, 2602, Australia; E-Mail: u4045668@anu.edu.au

External Editor: Dr. Robert G. Bednarik

Received: 8 September 2014; in revised form: 23 October 2014 / Accepted: 28 October 2014 /

Published: 11 December 2014

\begin{abstract}
Affordances necessary for the making of hand traces in the form of stencils and prints - primarily the availability of pigment and a suitable surface-bear on our understanding of their emergence as early exograms. Matters relating to the question of how pigment was/is applied, the placement and embellishment of images, the procurement and preparation of ochre, and the selecting and priming of surfaces, are discussed here-as well as the intriguing occurrence of variant hands. Advantage is taken of Australia's position as a zone of ongoing hand-marking practice to suggest what can be learned from ethnography. Finally, avenues for future research are proposed with a view to opening out a discussion of external information storage possibilities in relation to hand traces.
\end{abstract}

Keywords: hand stencils; hand prints; "decorated stencils"; "patterned hand prints"; ochre procurement; ochre preparation; pigment analysis; transposed gestural language; exograms

\section{Introduction}

We may postulate that hand-marking practices at known locations were culturally transmitted across distances ("diffusion"), or alternatively that they came to be made in diverse places as impulsive expressions of affordances answering the needs of people in particular environments. It is beyond the scope of our present knowledge to attempt an answer on this score, but this does not mean that there is nothing to be said and argued about. In fact, after many studies have been undertaken, much to do with hand stencils and prints is still in dispute. So my aim here is the modest one of revisiting basic technical aspects of hand-marking production (Figure 1), viz what has gone into their making. In a 
previous article in this journal I argued the case for the hand trace as a convenient external term lending itself to exogrammatic use. For a mark or object to function as an exogram it must mean something and that meaning needs to be accessible. The trace element of hand stencils and prints eminently satisfies this requirement, doing so in a minimal way by communicating information about the nexus of the biological self and its defining and shaping environment. Theoretical engagement with this nexus has in recent decades given rise to a new discourse on the subject of the "ecological self". My understanding of the term derives from cognitive psychology, in particular the founding studies of Neisser and his colleagues [1] working with concepts relating to the idea of "direct perception" developed by J.J. Gibson, whose focus was the perceiving organism extracting meaning from its surroundings. Meaning is present in the form of "affordances" which structure an organism's activities [2]. In the case of human hand-marking, the rock surface, the hand, and the traced hand are to be seen in the light of Gibsonian affordances generating in the first instance minimal meaning relating to the hand-marking agent's self-awareness as a negotiator of environmental spaces (distances, planes, obstacles, shapes and textures).

Figure 1. Numerous stock and "decorated" hand stencils, Major Art site, Mt Borradaile, Arnhem Land, Australia.

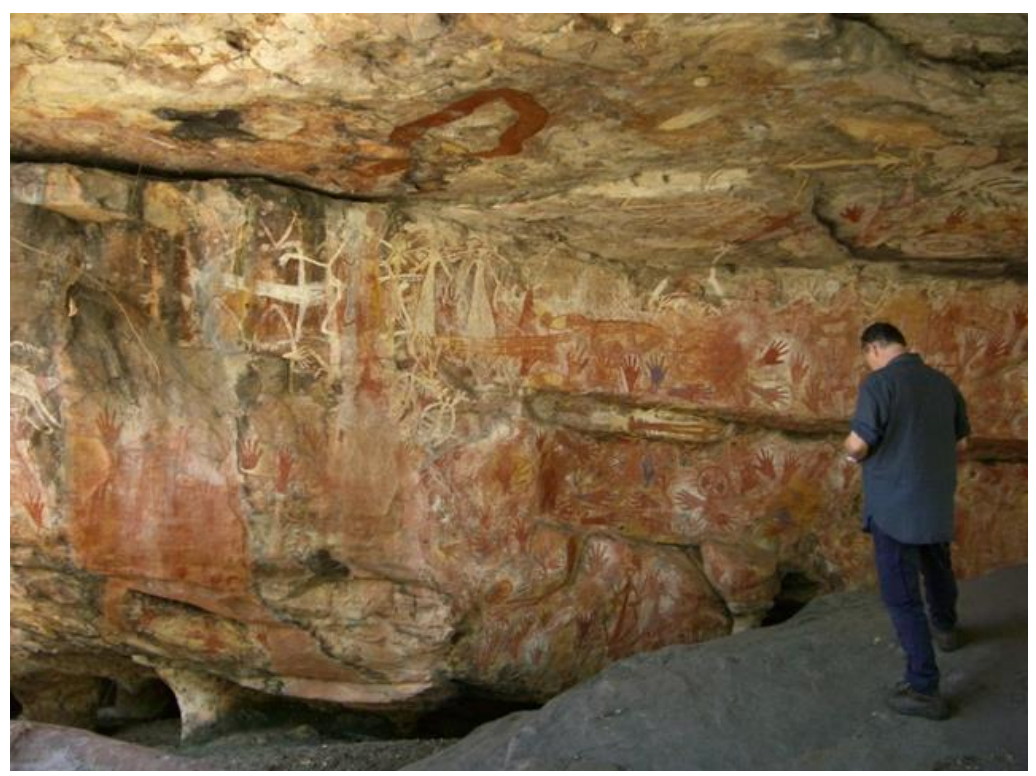

Importantly, the hand mark possesses what I term act-identity-alongside author-identity accessible if the maker is known. Act-identity, unlike author-identity ("signature"), is universally readable ([3], p. 296). I have chosen to distinguish these aspects of the hand mark image because what is described as "signature", viz the identity of a particular maker, is only decipherable through cultural knowledge, whereas "act-identity" is immediately accessible to any comer as a trace of an originatory action. Cultural meanings will differ from place to place, but the act of leaving a direct and recognisable trace of a hand provides a universal starting point for denotative elaboration. For details and citations I refer the reader to my argument set out at length in "The case for hand stencils and prints as proprio-performative" [3], the companion piece to this article. A "proprio-performative" image is defined as one which addresses the viewer directly and in a way which conveys information about the artist-agent. 
It should be noted that the art of stencilling has developed to include a large repertoire of objects besides the hands, hand and forearm. Even drawing examples from Australia alone (while acknowledging Australia's possibly unique diversity [4], p. 419), we have human and animal feet, the human body itself (rarely), implements, utensils, weapons, pendants, leaves, snakes, fish, mice, lizards, macropod legs and kangaroo tails, as well as whole birds and isolated images of a bandicoot, horse's hoof and mammal skin. (For a digest of finds with citations relating to the unusual among the above, plus evidence for the antiquity of recently-located whole bird stencils, see Taçon et al. [4]). A different kind of "composite stencil art" has been identified by Walsh in his management study of archaeological sites in the Queensland Sandstone Belt. According to Walsh, nets, zig-zags, “'ladders', 'trees', and even humanoid figures" previously regarded as a freehand painting style, are accomplished by an accumulation of stencilled units (sometimes in the hundreds) to form an independent motif through a technique of positioning and masking body parts and/or artefacts during pigment application [5]. With acknowledgement to Walsh, this technique was used by Lorblanchet (who had worked in Australia) in his well-known experiment reproducing the spotted horses panel at the French site of Pech-Merle [6,7], pp. 105-121).

Significant as the topic of stencilling is in general, the object of my inquiry is not stencilling as such, but the phenomenon of hand-marking. Hand-marking has created extraordinary sites around the world (from Patagonia's Cueva de las Manos to Australia's Carnarvon Gorge), sites which prompt us to ask why stencillers have so frequently and on such a large scale chosen to imprint their hands. Hand-marking possesses acknowledged special status in the rock art repertoire. In the context of the argument I put forward in the companion piece to the present article, it emerges as a form of iconic representation of the ecological self in action, a very particular kind of action which ultimately opens out possibilities for a visual language. See especially Sections 6.2 The "Ecological Self"; 6.3 The Rock Surface as Rudimentary Mirror; 6.4 Performative Images; 6.5 The Looming Effect and Representational Momentum; 6.6 Mirror Neurons and 7.2 A Definition in Dobrez [3].

My previous article has analysed the perceptual and cognitive aspects of hand-marking. But there are many ways of approaching hand stencils and prints in rock art. These range from remarking on them as manifestations of a universal human desire to record one's presence, to speculating about possible methods of production, symbolic placement of images on surfaces (and in relation to the surrounding terrain), associations with other images, and meaning within sign systems. Or we might note colour patterning and formal arrangement, treating a rock art panel as a discrete aesthetic object. Because we are eager to uncover what hand marks might add to our understanding of the human story there is an imperative to date them. Other empirical studies centre on attempts to determine the age, gender, handedness, and numbers of "authors" involved. A study of technics-rigorously carried out through observation, data analysis, appeal to ethnography and, where warranted, a testing of the field of the possible through replication experiments - can further our understanding of the role of image-making activities. My aim here is to comment on fundamental aspects of technique involved in the making of hand marks. However, to have a worldwide conversation on the topic we need to agree on what views we hold in common. So, with this in mind, my desire at the outset is to ask where researchers stand on a number of basic issues under discussion since rock art studies began to inquire into the who, how and what of hand stencilling and printing. 


\section{Definitions}

At this point in time, when a global conversation about rock art is more than ever possible through information-sharing and well-attended international meetings, it seems reasonable to ask that we attempt to reach some consensus about what we see as universal and what is patently culture-specific. Hand-marking is a global phenomenon. We can agree on this: it is a starting point. As soon as we begin to ask even apparently simple questions about how hand stencils are made differences emerge. Is the same true of hand prints? Can we agree on the way a hand print is made? Will the IFRAO English definition - "a positive pigmented imprint of a human hand, made by pressing a paint-covered hand against the rock surface"-satisfy everyone (Figure 2)? Certainly the IFRAO French "empreinte de main positive" and Italian "impronta di mano" descriptions contain nothing to contradict it ([8], p. 8, p. 84, p. 153). Sometimes a hand print will be called an "impression": "Impressions are made by pressing the palm of the hand, which has been dipped in paint, to the rock" ([9], p. 42). Unfortunately few of us are multi-lingual so a great deal of what the Rock Art Glossary might offer us by way of insights into diverse, and sometimes divergent, approaches will be closed to many. My hand stencil might look like yours but our understandings of the way it came into being and what it signifies might differ considerably.

Figure 2. Hand prints, Blue Dome site, Idaho, USA.

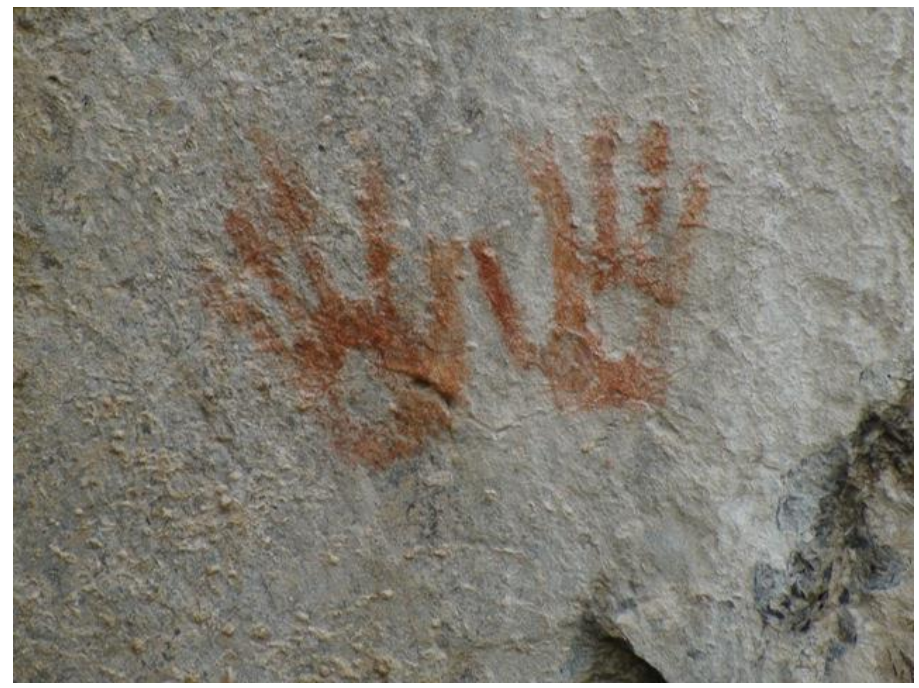

In any conversation it is important that a speaker's standpoint, or "subject position", is well understood. What any one of us has to work with in visualizing technical processes is exhausted in a list: finds at sites (e.g., ochre and implements), measurements, experiments, ethnographic descriptions - and hunches. Importantly, though, the way we shape our ideas will be subject to geographic and cultural influences. It is not surprising, therefore, that Europeans, unless they have worked elsewhere in the world, will tend to adopt positions influenced by the literature relating to Franco-Cantabrian sites. The British are caught between two worlds. Often they will have knowledge of Australia, once an outpost of Empire and a convenient place to engage in fieldwork. However, their closeness to the great French and Spanish sites, which since the 19th century have provided a critical arena for rock art research, sometimes means that they will regard conjectures made during the long 
period that these sites have been investigated as having special authority. For instance, a British university website currently up-and-running illustrates the acceptance of French theorizing as having universal application. Having mentioned prehistoric sites from South America, Africa and South East Asia, including Australia, the website author takes up a position entirely based on speculation about methods employed at Franco-Cantabrian locations:

The experimental replication of hand stencils shows that they were best produced by blowing watered-down pigment of runny consistency through hollow tubes, and the recovery of ochre-stained shells and bird bones below stencils in several caves reveals the specific equipment used to do this. A large bivalve shell was used to contain the runny paint, and a short tube inserted into it like a straw. Holding the ensemble close to the subject hand a second tube was used to blow across the first. This created a vacuum which sucked the pigment up from the shell as a fine spray. This created the characteristic diffuse cloud of colour around the hand, while revealing the hand in sharp outline [10].

The Groenen two-tubes hypothesis, difficult to visualize in operation, comes across as rather cumbersome, and the use of the qualifier "best" is surely not enough of an excuse for treating speculation as fact, however much its workability has been displayed in replication experiments [11]. A replication experiment, by demonstrating a method as unfeasible, may falsify a theory, but it cannot prove it merely by virtue of the fact that the method works. For a considered review of the "vaporisation à l'aide de deux tubes creux disposés à angle droit" method in operation see Le Quellec ([12], pp. 249-250). If we understand that the website quoted here is designed to showcase the research project of the team which in 2012 offered us a then oldest known date for hand stencils at El Castillo, Spain [13] — very recently overtaken by a finding for a hand stencil in a cave in Sulawesi, Indonesia [14] — we are able to place this description of technique firmly in the perspective of freewheeling theorizing about the caves of southern Europe, a theorizing which in its beginnings was unchecked by observations made by privileged ethnographers of the New World. Such is the force of tradition.

Even the notion of blowing through a tube, accepted by many, remains speculative, inference drawn from ochred bone tubes found at hand stencil sites. Clearly it would be good to have a review of all the candidate bone tubes found around the world. We do need reassurance that such tubes display clear evidence of having contained pigment - otherwise we might surmise that they were used to mix paint in shells or other containers. Added to this concern is an abiding suspicion that there might be a bias in some quarters towards answers centred on technology, as if complex tools were of themselves something to celebrate - the myth of progress being an unjustified but nevertheless spontaneous default position of many researchers.

For anyone seeking authoritative general information about Australian hand stencilling practice the ANU's Rock Art Research Centre offers the following description specifying what is thought to obtain in relation to Australian stencils:

Stencils in Australian rock art are made by mixing dry pigments (such as ochre, clay and charcoal) with water and/or saliva in the mouth and spitting the mixture onto the surface of the rock to create a negative image or outline of an object or body part. The most common stencil in Australia is the human hand (this is true of many countries around the world) [15]. 
Note the present tense: "are made", the point being that the making of stencils is a continuing practice in some Aboriginal communities. Australian research into the presence of saliva in pigment samples from stencil sites has been limited and there should be more analysis of this kind, but there is a wealth of documented observation of the ongoing techniques of hand-marking by indigenous peoples, encouraging speculation about past practice. Spencer and Gillen in Native Tribes of Central Australia (1899) note that stencilling the hands palm to surface by blowing ochre or charcoal from the mouth was "practised . . . all over the continent" [16], p. 616]. Herbert Basedow (1881-1933) also appears to be referring to a practice generally observed when he suggests in his 1935 text Knights of the Boomerang, which narrates his life among Aboriginal people, that they have "evolved a technique of their own" ([17], p. 102; [18], p. 261). The passé title of Basedow's book reflects his conviction (since overturned by DNA evidence) that Australian Aborigines were Caucasians - a view based on the discredited race theory of another age, but one which predisposed him to look with sympathetic interest for cultural parallels, one of them being the correspondence he sees between hand stencil imprints and written signatures. (For a discussion of Basedow and his historical milieu see Zogbaum [18])

Diverse reasons for the making of hand stencils are given in the literature. While at one location they will be made by as marks of respect ([17], p. 102) and at another as "fun" ([19], p. 19), in Australia at least there appears to be a continent-wide manner of producing them, as outlined in the following description by Basedow (backed up by others):

Briefly stated, the method is this. The visitor takes from a small plaited dilly-bag . . . a lump of pipeclay, and crunches it with his teeth. Retaining the masticated product on his tongue, he fills his mouth with water and makes a thorough mixture. Then placing his hand over the chosen spot, he squirts the contents against the back of it, so that the pipeclay suspended in the water splashes the rock all around. When the hand is withdrawn, a negative imprint of it remains, which may or may not be subsequently filled in with red ochre ([17], p. 102; see also [18], pp. 261-262).

Several important observations relevant to debates among rock art researchers are made here, and I shall comment on two of these presently, viz the clear picture which is presented of palms of hands held to the rock surface and the practice seen in some places of over-painting stencilled hands. From the point of view of the present discussion, it is Basedow's record of mastication of paint material which is of prime interest. The method is not exclusive to hand stencils. In this regard it is worth noting that an Arnhem Land painter on barks reported to Brandl that, when making a Rainbow Snake image on rock, he used his mouth as a receptacle for water and ochre and sprayed the mixture onto the image to create spots ([20], p. 105; $c f$. also McCarthy [9], p. 35); compare, as a matter of interest, the reputed technique of making spots on the famous horses of Pech-Merle, France [6,7], p. 479), and for mention of further Australian ethnographic sources recording blowing from the mouth see Dobrez [3]).

McCarthy, allowing an alternative method of production, has this to say about Australian stencils in general:

The stencils are made in two ways, either by blowing powdered pigment from the mouth or from a little sheet of bark on to a wetted surface, or by blowing liquid pigment from the mouth, on to a dry surface, around an object held against the rock ([9], p. 38). 
Humans are resourceful and any imagined plausible method should not be ruled out. It is important to remember, however, that materials like bark are perishable and will not remain in the record. While accepting direct spraying from the mouth, the Bradshaw Foundation website relating to "World Rock Art" adds expulsion of "charcoal powder through a reed" [21]. Malvesin-Fabre et al. ([22], p. 14) suggest that hand stencils at Gargas in the mid Pyrenees, France, might have been produced, not as iconic images made in their own right, but as accidental by-products of an activity of body-painting where holding a hand against a wall would be a matter of convenience rather than intentional design.

An early Gargas theory proposed that the process involved projecting powder onto a moist surface. This theory is, however, dismissed by Barrière who argues that the stencils' characteristic stippled haloes could not have been achieved in this fashion: "a dry coloured powder sprayed on to a damp rock face does not give the spattering effect . . . and almost always gives 'fall-out' below the hand, a feature which is never seen at Gargas". Methods clearly vary between sites around the world. At Gargas there are stencilled hand images which appear to have been made by dabbing with a pad, thus producing "a regular area of paint around the hand and no diffused halo" ([23], p. 76).

Notwithstanding variety in pigment application, blowing from the mouth has been reported by ethnographers in so many Australian contexts that it cannot fail to be described as a dominant technique. Unfortunately a means we have available to help us make up our minds about this crucial aspect of stencilling has only limited application. Saliva possesses a detectable carbon signature, but this marker diminishes over time. So, it is a matter of frustration that pigment analysis able to supply evidence for the presence of saliva in paint - thus supporting the blowing from the mouth thesis-is defeated when dealing with stencils older than a few hundred years ([24], p. 92). If the "Australian method" were to be emphatically established across the world, its status as a technical universal would prompt us to ask radical questions about its genesis. Might not the architecture of the brain itself, the product of long-established patterns of interacting with the world, dispose the human organism to pre-set sequences with neural underpinning from those localized areas of the cortex coordinating control of face and hand? We might look to Broca's area, the motor site for speech, which recent studies have implicated in the development of language-readiness through an already existing gesture recognition apparatus [3].

\section{Placement}

To the extent that the body itself functions as a tool [3], placement of an image comes under the heading of technique. Of course motives of a cultural sort, like the superimposition of hand stencils on special images at sites of increase, come into play in potent ways. However, these motives do not impinge on matters of technique pure and simple. Just where a hand image, stencil or print, is placed on a rock surface will be determined in the first instance by the capabilities of the human body, including the ability of one human to assist another, and in the second by any possible supporting apparatus which might hypothetically have been employed, such as a scaffold. It should be noted, however, that placement of hand marks usually correlates with the apparent age and stature of their makers - as judged at least provisionally by hand size ([25], p.109). At sites around Laura, Cape York, for example, intimate ground-level shelters feature small hand stencils (Figure 3) which appear to be the work of children (S. Trezise, pers. comm. 15/8/2014). Instances have been recorded of supposed 
children's stencils at heights suggesting lifting by adults ([25], p. 109; [26], p. 14), and "adult" stencils have been found in difficult places where the alternative explanations must be: (a) that an athletic exploit is involved; (b) that floor levels or wall contours have changed over time; or (c) some engineering feat is implicated. Witness these stencils placed at height at Cueva de las Manos, Argentina (Figure 4), and, more strikingly, stencils occurring at up to ca. $8 \mathrm{~m}$ (25 ft) height at a site in Cape York, Australia (Figure 5). Comments comparable to the above may be made of positive hands. In the Victoria River region, Northern Territory, Australia, McNickle has recorded one site where "well over one hundred hand prints have been placed on the wall, many of them well above unaided human reach" ([27], p. 40). In connection with north-west Australia, Walsh asserts: "ancient imprints have commonly been applied in inaccessible areas, at times $20 \mathrm{~m}$ (65 ft) above floor level” ([28], p. 94).

Figure 3. Small shelter with children's hands, Cape York, Australia.

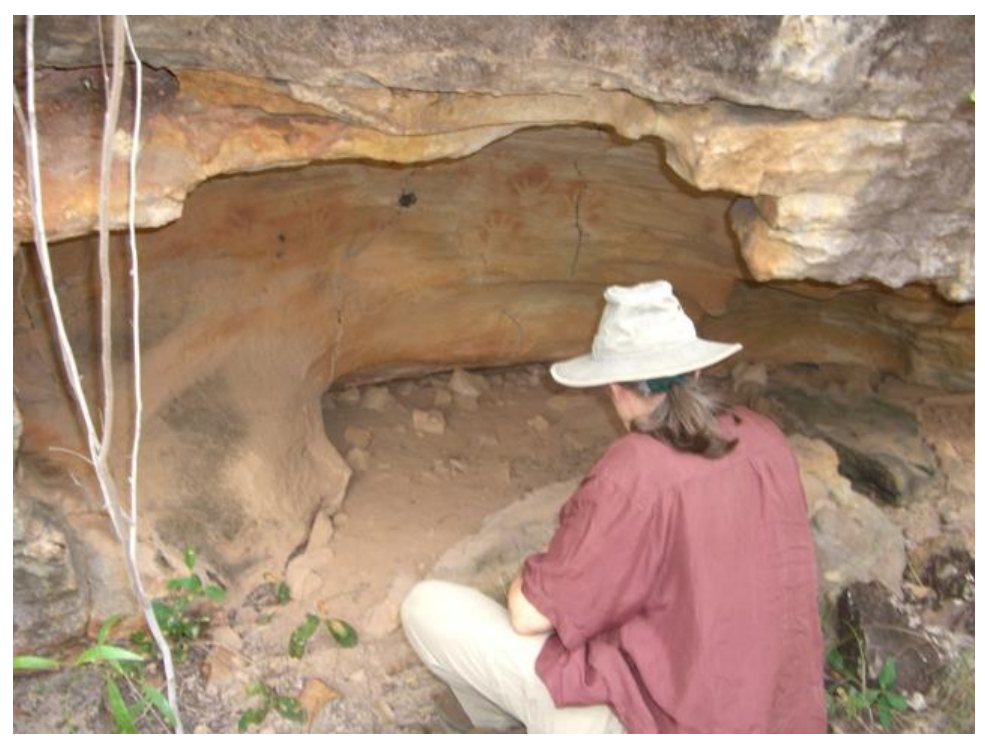

Figure 4. Stencils at height, Cueva de las Manos, Santa Cruz, Patagonia, Argentina.

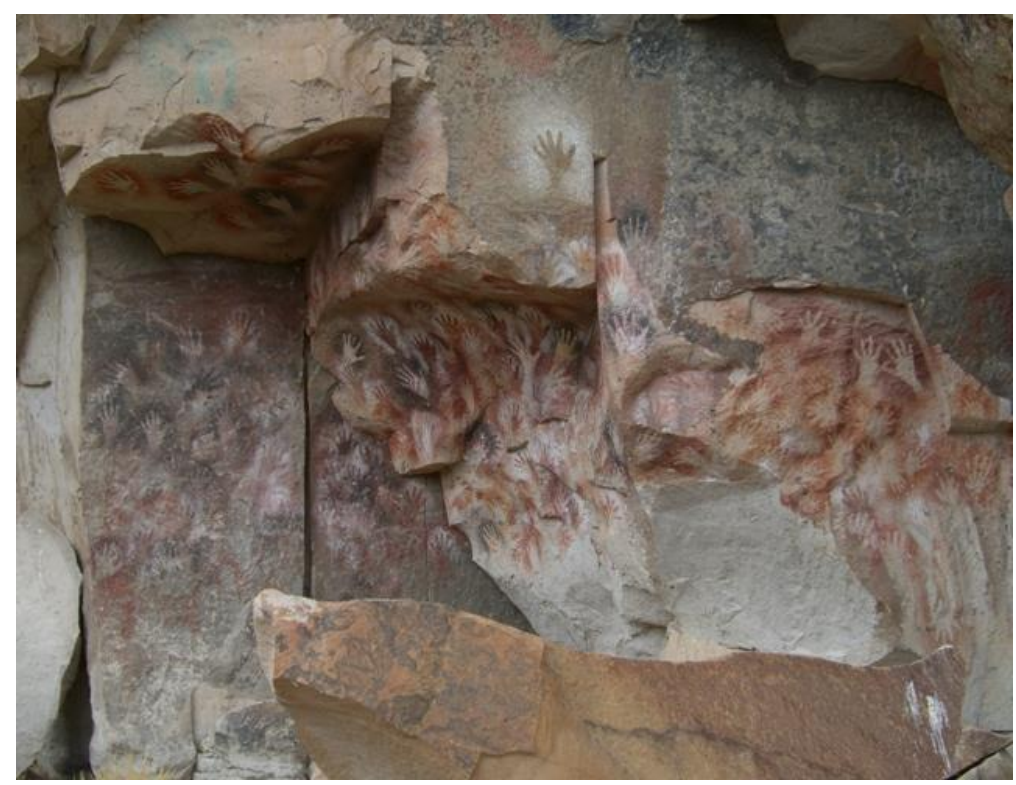


Figure 5. Stencils at great height, Gugu-Yalangi, Cape York, Australia.

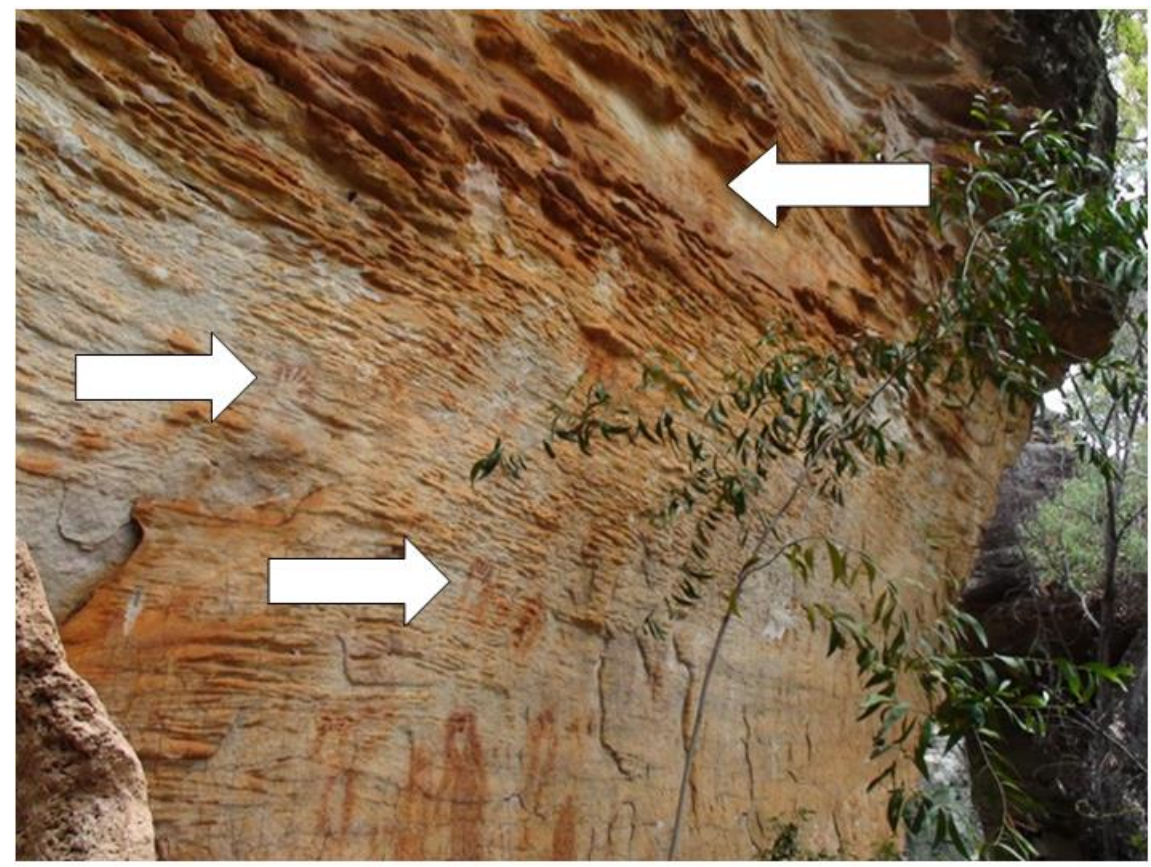

\section{Embellishing Hand Images}

\subsection{Decorated Hand Stencils}

Decorated hand stencils have been recorded at various sites around the world. A notable site exists at Mt Borradaile, in western Arnhem Land, Australia, where stencilled hands have been converted into images looking like decorated positive prints. This has been accomplished by first over-painting them, then adding patterns. Comparable images are found elsewhere in Arnhem Land and are referred to in the literature as "decorated hands" (Figure 6). McCarthy describes them thus: "In the Oenpelli region of western Arnhem Land the hand is painted yellow inside the red stencil, or an elaborate decorative line pattern is painted on the hand and arm" ([9], p. 38). It has been suggested that in some areas they are representations of gloves seen by Aboriginal people during the contact period ([29], p. 214). (For discussion of a different explanation, viz a masking of the stencils of the dead, see Dobrez previously in Arts [3].) At caves in Borneo instances of the decorated hand will feature dots, lines and other markings which, in contrast to the Mt Borradaile images, do not serve to mask the original stencil blank. At the Western Australian coastal site of Willigulli we encounter stencilled hands with the unusual addition of painted fingernails (Figure 7).

Applying supplementary colour or an added shape to a stencil negative in order to embellish it in some way is to be included in a broad discussion of technique. Clearly such visual elaboration has the potential to open stencils out to extended symbolic use - to indicate affiliation to a particular group, for example. (Whenever one term - this might be a shape, a colour, a sound, a texture, any distinguishable attribute of the perceived world-is substituted for another in a meaning equation the descriptor "symbolic" is justified. Information storage systems depend on this type of substitution.) Or in any particular instance it may simply be a case of decoration for its own sake. 
Figure 6. Decorated hands, Mt Borradaile, Arnhem Land, Australia.

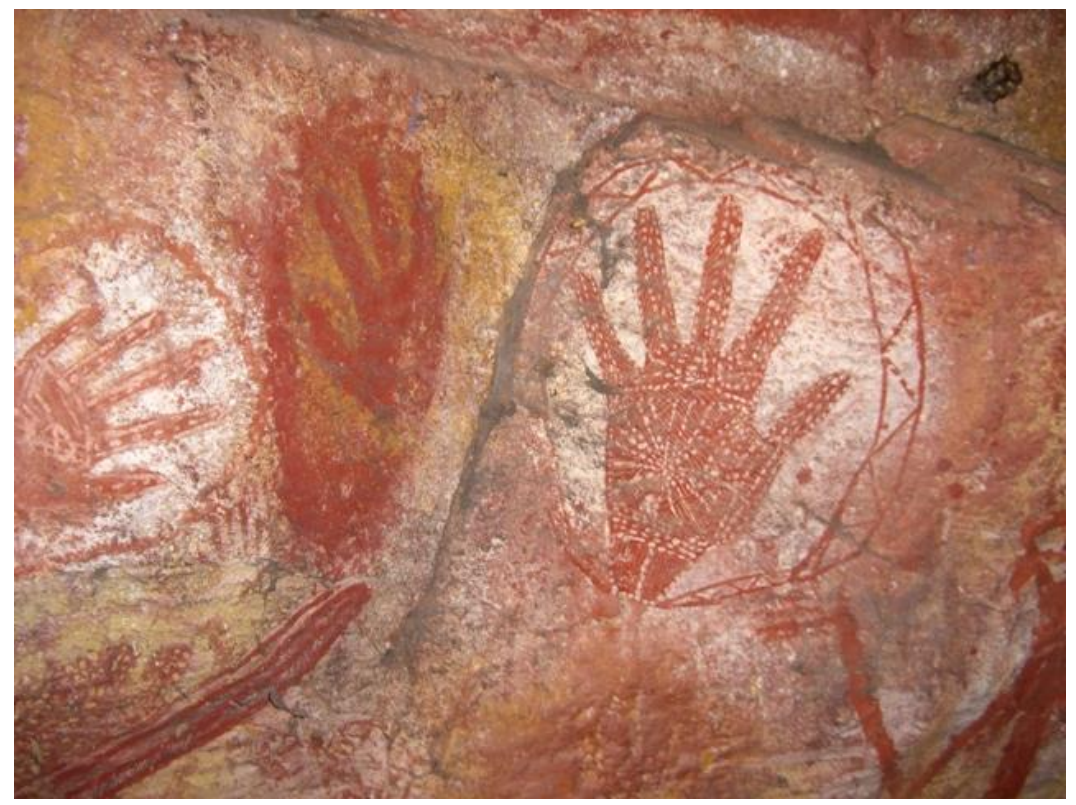

Figure 7. Hand stencils with painted fingernails, Willigulli, Western Australia.

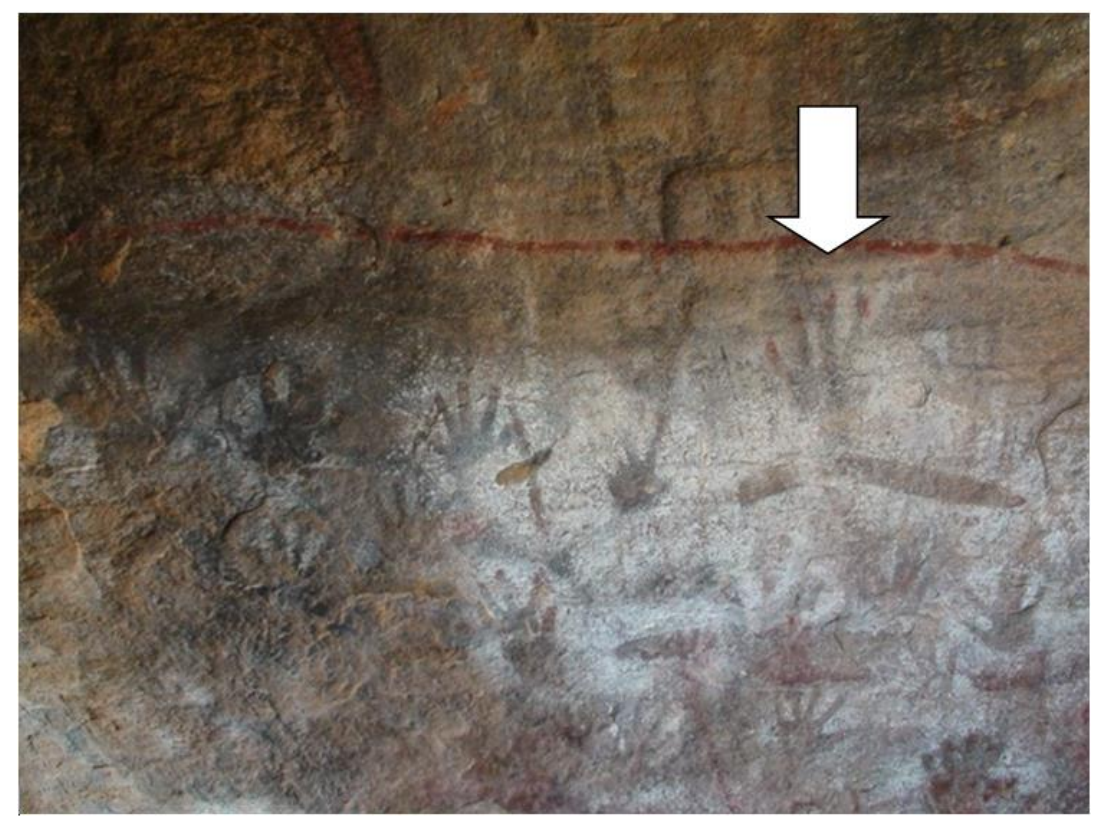

\subsection{Patterned Hand Prints}

A glossary found at the Australian National University's Rock Art Research Centre website offers a definition of hand prints which embraces the notion of the "patterned print". The patterning method it specifies is, however, not the usual one encountered:

Hand prints are made by dipping the palm of the hand in wet pigment and pressing it onto the rock surface. In some parts of Australia (such as western and north western Arnhem Land) hand prints can be in-filled with painted patterns after [italics mine] the print is made [15]. 
On the other hand the following quotation from the IFRAO Rock Art Glossary is in line with observations made at a number of sites around the world (for a list see [3], p. 286) and put to the test of replication by Gunn at a site in the Levi Range, central Australia [30]:

Patterned hand print - a hand print in which a pattern has been painted prior [italics mine] to printing ([8], p. 1).

With its parallel use of the word "avant", the French IFRAO glossary definition of an "empreinte de main avec dessin" (Figure 8) conforms to this description ([8], p. 84). Since both methods are feasible-i.e., executing decoration after printing and before - a comparative study of examples of the patterned hand would help to clarify the matter. It is important to note that confusions can arise when one language is translated into another or when writers or speakers use a language which is not their own. A French researcher might speak of "negative prints", meaning stencils, then slip in to the shorthand "prints", which in English denotes positives.

Figure 8. Patterned hand prints, central Australia (courtesy R. G. Gunn).

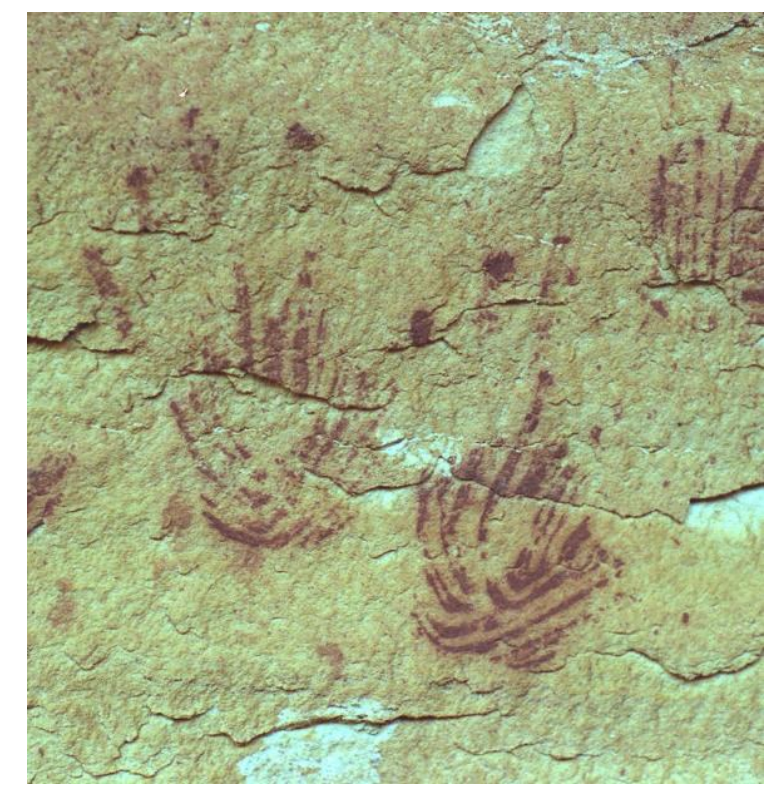

\section{Procuring and Preparing Ochre}

Like all rock art dependent on ochre supplies, hand stencils and prints require either a ready local hoard or remote access available through travel and trade. Sometimes pigment will have been sourced from nearby creek banks and quarries; at other times it will have been brought from afar. McCarthy suggests likely procurement by "barter or gift" ([9], p. 34).

\subsection{Ochre Mining}

The section on the "Technology of Pictograms" in Bednarik's Rock Art Science ([31], pp. 48-50) provides a useful summary of world knowledge about the mining of ochre, a critique of methods which have been employed in analysing paint residues, and survey of work which has been done on the preparation and sourcing of pigment. Bednarik's account of the procuring of ochre at different sites around the world points to the antiquity, widespread practice and sometimes intense nature of mining 
it. Mines have been found which have obviously been in use over a long period of time, since it is apparent that very large quantities of material have been extracted. There is also evidence of task-specific tools of wood and stone having been used in the process, as well as scaffolds ([31], p. 46). McCarthy has described the massive enterprise of the Wilga Mia mine in the Weld Range, Western Australia, a major centre from which ochres were traded over extraordinary distances:

The ochre was got out by under-cutting masses of rock, and by battering away the matrix with heavy stone mauls. Hardwood sticks were driven into the ochre to pry it out. Pole scaffolds were erected for working at various heights. The lumps of stone were usually carried to the top of the northern slope where they were broken up to get the ochre, and it was carried away in bags of $10 \mathrm{lb}$ or more.

The man hours involved suggested "centuries, possibly millennia of use" at a site still being worked in 1939 ([9], p. 35). Notable for its supports, shoring, platforms and other devices, Wilga Mia mine has National Heritage listing. Of course, when it comes to technology, even small-scale operations may involve improvised implements. Brandl records how "a branch with a suitable fork" was used at Cadell River in Arnhem Land, Australia, to store soft clay taken from the bed of a water-hole ([20], p. 106).

\subsection{Special Ochre Preparation for Hand Stencils?}

We need to take into account that ochre supplies used for other purposes-body and implement painting, and pictographs - may not have been used for stencils. More extensive comparative work than that already undertaken is needed to establish any significant differences which might exist between painted images and stencilled ones-differences which might arise as a consequence of the involvement of the mouth, and could be influenced by the masticatory factor and/or a ritual one. Commenting on stencils of hands and other objects at Carnarvon Gorge, Queensland, Australia, Elkin cites records made by Rev. L. Hayes of the 1937/38 Carnarvon Ranges expeditions, suggesting that "Aborigines merely broke up ... pigments and liquefied them by placing them in their mouths". In his own view, however, pigment underwent a pre-processing, since he had seen stencillers "mix ochres with water on a rock before putting them into their mouths" ([32], p.114).

Pigment analysis in Australia has shown a difference in consistency between paints used for stencilled and iconographic images at targeted sites. Cole and Watchman's research at Laura, Cape York, has shown that stencil paint is "more highly processed" than that used to make pictures. This on the grounds that, without pigment particle size being any different, "quartz grains from stencil paints were smaller than those of iconographic motif paints" (cited in [24], p. 92). Such dissimilarity between stencils and pictographs has been confirmed by Huntley et al. on the Woronora plateau, New South Wales, where finer quartz grains and carbon peaks associated with saliva have suggested special processing preceding mastication, as well as "further processing of the paint in the mouth": "for instance if the clays were chewed prior to being applied to the rock matrix". As mentioned above, saliva carbon signatures diminish over time and, after several hundred years, will have disappeared ([24], p. 92). Thus the presence or absence of the carbon signature might be used with caution as an indicator of possible dates. (On a general cautionary note, attention should be paid to Huntley [33] discussing taphonomic issues in sampling for pigment analysis.) In relation to rock art at 
Laura, Cape York, Australia, Ward et al. have remarked on a white hand stencil distinguished by the use of huntite from other white paintings in the area with a quite different mineral composition. Although this might have been "a random event", we can speculate that trading in a rarity had taken place ([34], p. 20-21).

\subsection{Colorants and Fixatives}

The variety of mineral, vegetable and animal material involved in rock art pigment preparation shows that artists were attuned to the field of the possible when it came to finding colorants and fixatives: if something worked, it would be utilised. In Arnhem Land, for example, missionaries supplied synthetic blue colour ([29], p. 214), probably in the form of commercially-available Reckitt's "blue" knobs (Figure 9) used for whitening a wash. Because of its likeness to ochre, perhaps, or for its dazzling "French ultramarine" shade — or the alternative "Prussian blue" (also known as "iron or Paris blue"), [35], p. 58) - it was taken up enthusiastically for decorating stencils and for other painted images (Figure 10).

Figure 9. Reckitt's "washing blue" used in decorating stencils, Arnhem Land, Australia.

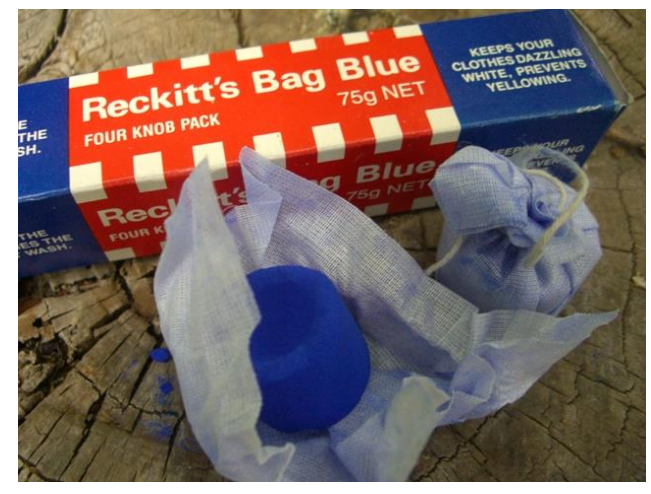

Figure 10. Blue decorated hands, Mt Borradaile, Arnhem Land, Australia.

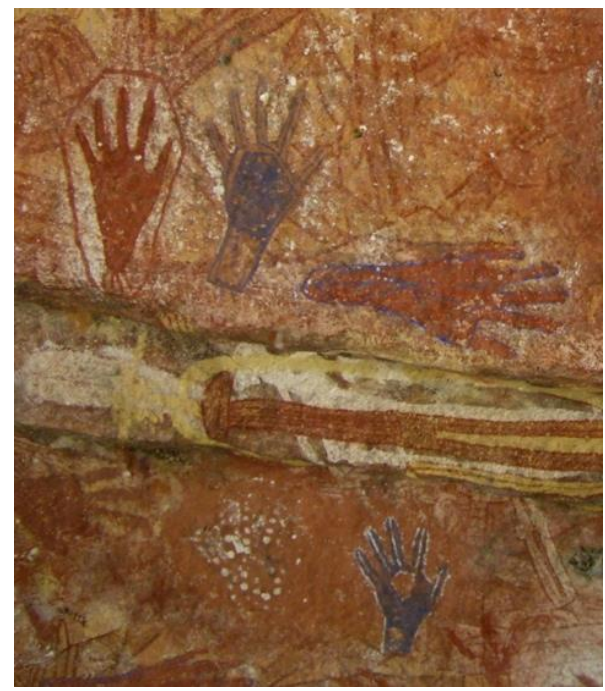

The range of colours employed at sites around the world is impressive. The justifiably celebrated Patagonian site of Cueva de las Manos, with its varied spectrum of white, black, yellow, red, violet and 
green effects (see Wainwright et al. [36] for pigment analysis), illustrates how mineral diversity can be taken advantage of with spectacular results (Figure 11). Taphonomic logic suggests that palaeo-sites now exhibiting only two or three colours may originally have had a broader palette. Opinion has been divided on the question of achieving special colour tones: whether via superimposition as a means of altering tone or the deliberate sourcing of desired pigments. It is reasonable to assume that both methods were employed ([20], p. 106).

Figure 11. Cueva de las Manos, Santa Cruz, Patagonia, Argentina.

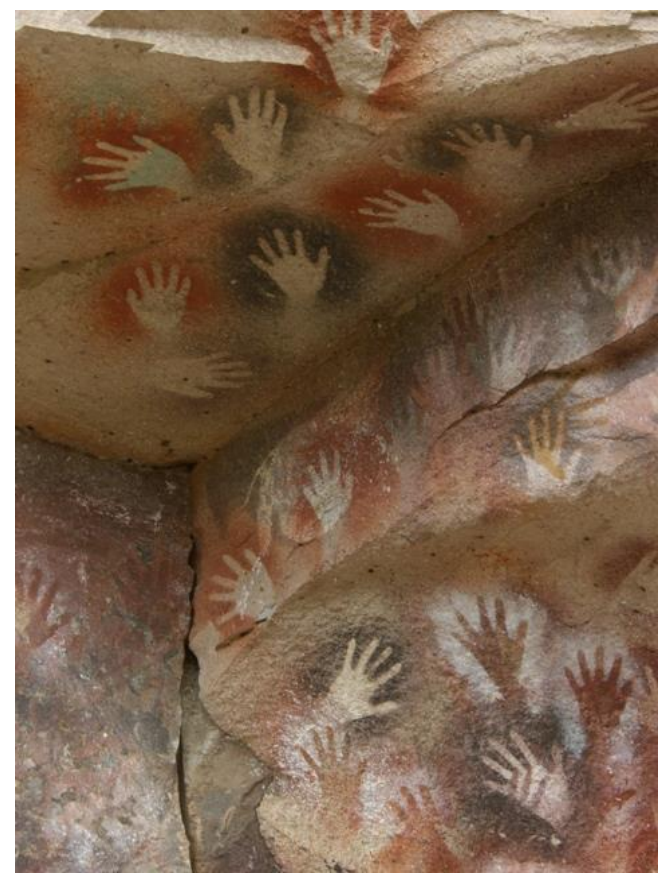

Ethnography in Australia tells us that artists possess specialised names for different ochre materials, to the extent of employing different terms for different hues. One example, from Deaf Adder Creek, Arnhem Land, involves the concept of "cooked" and "half cooked" for shades of red and yellow - possibly relating to changes in chemical composition through heating ochre ([20], p. 106). In the preparation of pigment for bark painting, a fixative such as an orchid bulb crushed in the mouth might be applied directly to the bark and also on the stone palette used to mix the pigment, a practice which Mountford records as also applying to rock art (see Cole and Watchman, [37], p. 30). In addition to plant juices and saps, in particular that of the orchid, Bednarik lists candidate "solvent, suspender or binder" liquids as: "water, urine, blood, semen, honey, eggwhite, or the fat of various animals", remarking also that surfaces bearing signs of pigment-crushing are found in abundance at rock art painting sites ([31], p. 47).

Cole and Watchman's study of fibres in paint samples from Laura, Cape York, Australia, suggests debris had been incorporated "from wooden implements or utensils used in a range of activities associated with the collection, preparation or application of paint, and/or plant matter included in the paint process for fixative purposes" ([37], p. 33). However, there is nothing to suggest that stencils were especially targeted in this study. Obviously this would be a worthwhile exercise. The question of the kinds of additives to be found in paint used for stencils on the one hand and prints on the other 
needs specific investigation, especially at a target site where both are present and understood to be contemporaneous, as this might possibly indicate special preparation in the case of stencils.

\section{An Ethnographic Reality-Check}

It is important to recognise that not all questions will be answered by appeal to criteria relating to the mechanics of an operation. For example, the notion that there might be a plausible non-practical reason for spraying saliva-mixed pigment from the mouth (at one level, of course, the method is practical, eminently so, since it works) is suggested by a recorded preoccupation with, and ritual attitude to, bodily fluids among some groups for whom a stencilling tradition is still alive today. Many such attitudes, much like poetic/metaphoric elements in modern languages, will have a longevity relating to a long lost-sight-of origin. Spencer and Gillen remark on a central Australian practice of "spittle-throwing" ("Puliliwuma") — a form of magic intense enough to cause the targeted person to waste away ([16], pp. 552-553). Elkin speaks of blood being used as a sacred, efficacious, ex opere operato substance in ceremonies of increase "not only to paint the totemic emblems on the actors' bodies or to decorate some symbol, but also to anoint the stone which is the permanent [totemic] symbol" ([38], p. 225). Meaning attributed to particular bodily fluids will, of course, vary from place to place, but this is not the issue: it is the general fact of their being significant which is relevant here. The great ritual cycles of fertility, procreation and renewal of Arnhem Land employ as major poetic tropes water, blood and semen, together with ochre for body-painting. All four liquids are woven in a powerful way into the Goulburn Island Cycle performed as a prelude to the coming of the monsoon ([39], pp. 47-72). In western Arnhem Land, Australia, the "sweat" of a dead person is regarded as a spiritually powerful substance. As recorded in 1982, Kunwinjku people hold that "you have to wash it ["sweat"] away and you have your own body back" ([19], pp. 108-109) — this in the context of a washing ceremony which removes the influence of the dead from the living. Might not beliefs such as this when related to saliva - beliefs which would give added meaning to the notion of a stencil as so potently idiosyncratic that it can act as a stand-in for an absent or dead person-help to explain the twin practices recorded at Arnhem Land sites (1) of acknowledging the "living" portrait embodied in the trace hand and (2) of masking the stencils of the dead to erase this influence ([3], p. 285)? In this way the power of bodily fluids might be expected to influence the practice of mixing pigment with saliva.

At Balgo in the Great Sandy Desert, central Australia, where there is a tradition of image-making in the earth itself, i.e., "sand drawing", great emphasis is put on the importance of touching. Reflecting an overarching world-view, words in languages of the area which refer to the making of both painted images and those drawn in the sand are said to "cluster around ideas of touching, poking and piercing" ([40], p. 52). When pondering hand marks and the way they are produced, it might help to think about what else might be shaping technical practices, viz an elaborated (symbolic) meaning which in all likelihood retains a link with an originatory real-world act. In the case of expelling liquid pigment from the mouth to record a trace of a hand making contact with a rock surface, we could be looking at ethnography that relates to the ritual significance of the practices of touching, the laying on of hands, non-stencil-related cases of expelling liquid from the mouth, as well as concepts relating to breath and speech. 
The likelihood of symbolic significance being invested in every aspect of hand stencilling, from the outset of ochre collection (for instances of mythologies and rituals centred on sacred pigments see McCarthy [9], pp. 34-35) to placing the hand on a rock surface, should make us wary of assuming that technical choices in image-making are driven by mechanical considerations alone. Indeed it makes sense that, in many instances, technique - provided it works - will be subservient to considerations of cultural importance to a group, especially those which have their origin in a people's direct relationship with an environment. An approach centred on technē alone, often governed by 19th-century progressivist notions, will not suffice. At its most misguided, it encourages an ungrounded hypothesizing about the involvement of possible tricky mechanical apparatuses in situations where quite different impulses and motives are clearly in play. Where rock art is concerned, considerations of an ecological kind provide a safe starting-point, biology "exuding"- to employ Leroi-Gourhan's term when discussing our first tools ([41], p. 106) - the symbolic. When considering the symbolic, we should be looking as much as anywhere else to the biological.

In its basic expression, hand-marking is interesting because it is technologically unencumbered. The body itself is the tool, producing readable external iconic images strategically placed for information-storage (in the first instance information-storage in the form of traces of bodily acts [3]). With stencils, hand, mouth, ochre and a rock surface provide the wherewithal; with prints, hand, ochre and a surface. In view of this, I would suggest that a clearer, more candid testament of an organism aware of its ecological niche cannot be found than hand-marking - and that the act reflects the human hand's special status in species definition ([3], pp. 273-275).

\section{Selecting and Preparing Surfaces}

Clearly not all rock art surfaces are suitable for paint application and in most cases these are avoided. What appeals as a suitable surface, however, will sometimes surprise. At Laura, Cape York, Australia, stencils are to be found on a pock-marked surface (Figure 12). At the spectacular Patagonian site Cueva de las Manos there are instances of stencilled images standing out sharply against clean surfaces. On the other hand, there are also walls displaying a palimpsest of superimposed hands and layered colour (Figure 4).

Figure 12. Stencils, Gugu-Yalangi, Cape York, Australia.

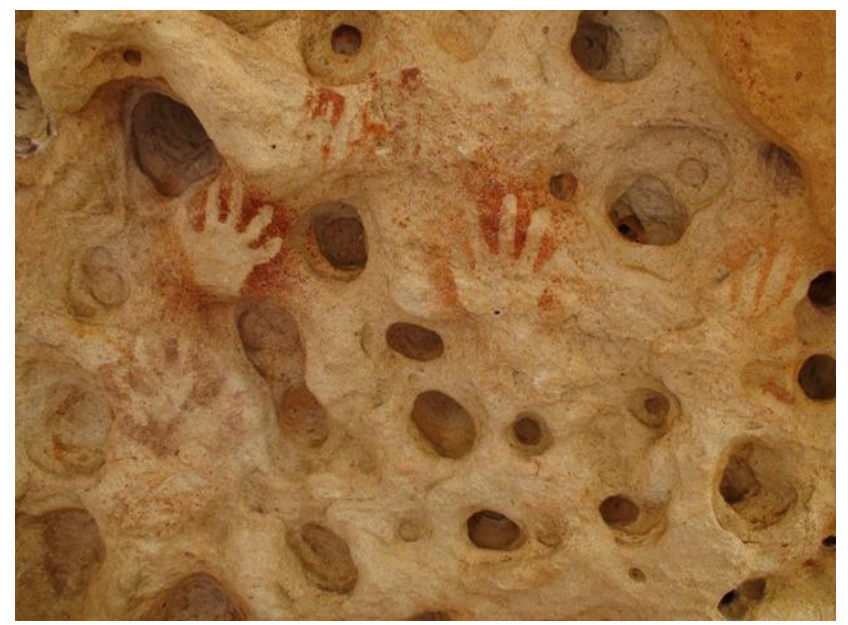


The choice of "framing" niches, like the famous one enclosing a single black hand at Gargas or other rock features conducive to display, is not uncommon (Figures 13-15).

Figure 13. Cover, Malvesin-Fabre et al. : Gargas: La Terre et L'homme.

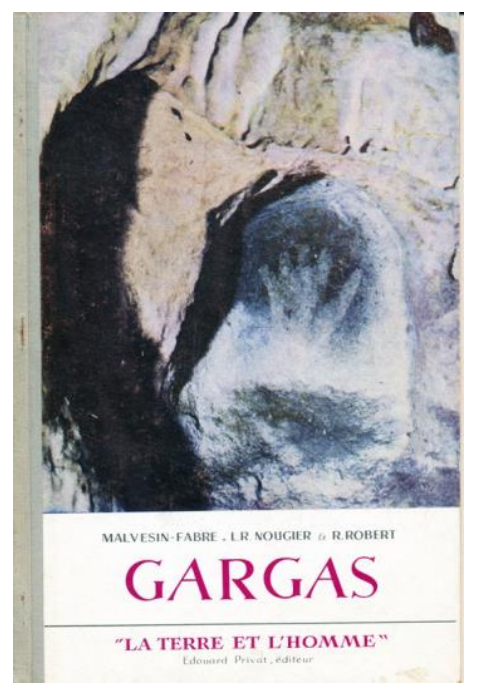

Figure 14. "Framed hands", Woronora, New South Wales, Australia.

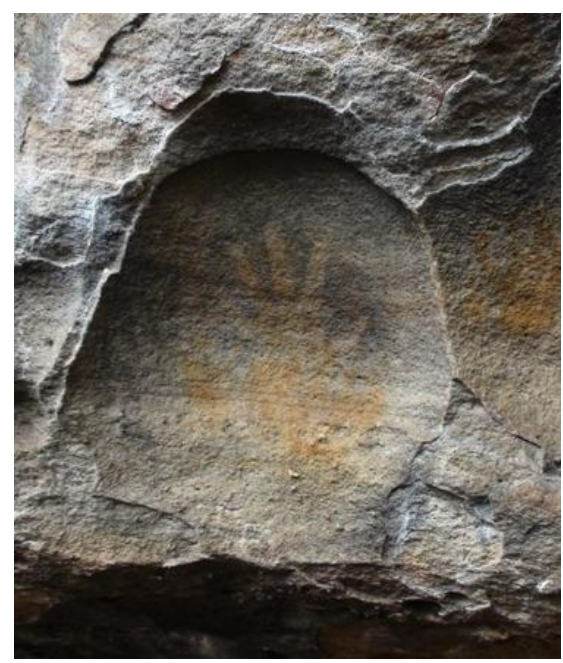

Figure 15. Enigmatic “framed” hand image, Baby’s Feet Shelter, New South Wales.

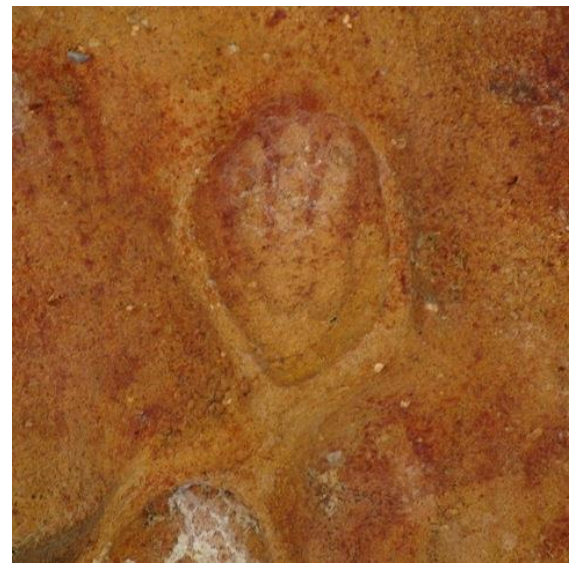


Surface preparation has been identified by Gunn [42] at Mulka's Cave, Western Australia. Such a method is seen as "a feature" of the site, where 35 stencils - white-on-red negative images which, because of subsequent weathering, look like positives-were made on a pre-pigmented surface. However, Gunn is at pains to point out that it is not possible to judge definitively whether the surface was prepared for the purpose of stencilling or simply provided a suitable area for making images. Mathews suggests the preparation of surfaces by dampening, after which dry powder is blown from the mouth "where it appears to have the durability of ordinary pigment" ([43], p. 147).

\section{Varying the Stock Hand}

\subsection{Mutilation?}

For a very long time theorizing about hand stencils with incomplete fingers centred on the French site of Gargas, which meant that even in Australia, where it might be thought that independent views would spring up, writers on the subject tended to present their arguments in oppositional terms, either for or against, by referencing French speculations about finger amputations, frostbite, Raynaud's disease, leprosy and other pathologies. The extent to which battlelines are set up in the first decade of the 20th century endured is illustrated by Walsh's landmark article on central Queensland sites with its telling title "Mutilated Hands or Signal Stencils?" [44]. The article's publication date of 1979—some years after Leroi-Gourhan [45] had set his gestural-language cat among the pigeons (see discussion below) - suggests a time-lag in Australian engagement of the issues.

The widely-circulated 1911 book Ancient Hunters, by W. J. Sollas, gave currency to recently-published interpretations of Gargas stencils by setting out the pros and cons of the mutilations case advanced by Breuil's collaborator at the site, Cartailhac. Sollas' enthusiasm for the subject was such that he had his female assistant help him reproduce the negative results of Cartailhac's experiments which had claimed to show that the hands missing several fingers found at Gargas could not have been fashioned by bending fingers. However, with not too much effort, Sollas and his assistant found that in large part "the appearance of amputation can be obtained" (my italics). Notwithstanding this outcome, Sollas bowed to Cartailhac, citing, as supporting evidence of his theory, claims of amputations, not only of the little finger, but the 2nd and 3rd among South African Bushmen ([46], pp. 238-243).

Halfway through the century a brief French monograph drew on the earlier work of Cartailhac and Breuil to present Gargas as the grand “"temple' de la main", but a temple dedicated to some (monstrous, as the authors apprehend it) practice of ritual amputation. The appeal here was to ethnography from diverse places, including North America and Australia ([22], p. 5, pp. 12-14). In fact Plains Indian rock art scholar James Keyser confirms the veracity of the Malvesin-Fabre et al. claim that Mandan cut off fingers - adding also Hidatsa and Crow to the list (pers. comm. 5/2/2014). However, this does not alter the fact that early interpreters-predisposed as they were to exaggerate differences between the prehistoric past and post-Enlightenment present - too readily leapt to ritual amputation to explain incomplete hands. From the outset, Malvesin-Fabre et al. make us aware of their profound culture-shock, shared by other Europeans, at the prospect of voluntary maiming: among the Franco-Cantabrian caves Gargas continued to stand out as the Temple of the Hand, exhibiting the shuddering spectacle of "des mains mutilées, des mains aux nombreuses phalanges 
sectionées, des mains devenues de terribles moignons et dont la seule vue cause un malaise profond et indéfinissable" ([22], p. 3; for an Australian parallel to this reaction see Dobrez, [3], p. 311).

\subsection{Transposed Gestural Sign Language?}

It was Leroi-Gourhan [45], backed by influential rock art scholars like Clottes and Courtin [47], who effected a decisive change in the discourse of variant hands by pursuing the idea of a transposed gestural sign system involving the manipulation of fingers in the production of stencilled equivalents of gestures. From the point of view of the technique of stencilling, we can call it the "bent fingers hypothesis". In respect to Leroi-Gourhan's "langage gestuel" hypothesis as an alternative to amputation, it is important to take note of the superior agility in hand manipulation of makers of stencilled hand images, viz of peoples skilled in tool-making and tool use, carving and weaving, activities of seed gathering and grinding, the flaying and dismembering of animals and, not least, sign language itself. Illustrated examples given by ethnographer W. E. Roth [48] of signs from Queensland, Australia, draw attention to Aboriginal gestural dexterity (Figure 16). Contrary assertions about the limited manoeuvrability of the human hand have been made by those who, following Cartailhac, want to dismiss the proposition that variant hands of the kind found at Gargas might have been produced by bending fingers (see Barrière, [23], p. 81).

Figure 16. W. E. Roth, Ethnological Studies among the North-West-Central Queensland Aborigines, 1897: Plate II, Figures 1-24, showing examples of sign-language hand gestures signifying mammals.

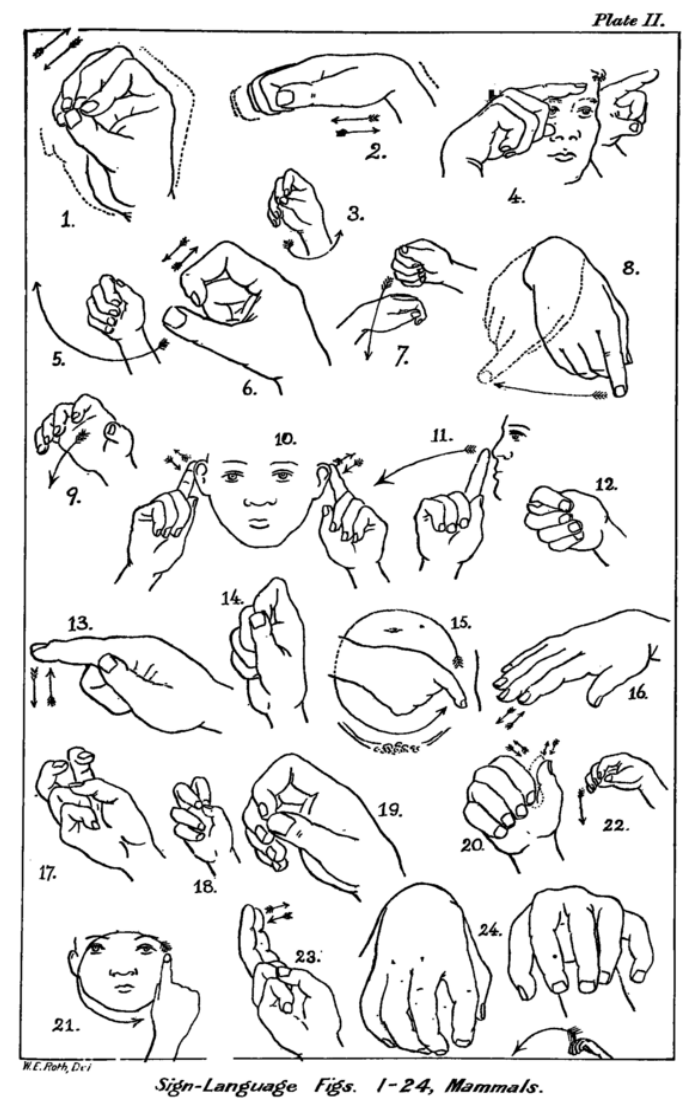


The signals Roth documents denote an extraordinary range of mammals, birds, fish, insects, plants, humans in their family relationships, ornaments, weapons, implements, utensils, notions of locality and direction, activities, states of mind, moral qualities and emotions, thus showing the versatility of the hand in making a large variety of distinct and recognizable forms. How much of such a repertoire could be taken over by stencil art is an open question and it is possible that what we encounter in rock art panels like those in central Queensland and elsewhere (Figure 17) represents only a fraction of what the hand in actual movement is able to communicate. Nevertheless, the efforts of Walsh [44] and Wright [49] to match static stencil images with documented dynamic gestural language signs (Figure 18) have laid the groundwork for what should be a continuing exploration of this likely connection. For a discussion of the contribution of Walsh and Wright see Dobrez ([3], pp. 288-289). A recent article on the stencils of Gargas and Cosquer has compared their varying of the stock hand with modern finger-counting systems recorded in ethnography, arguing for the encoding of hand stencils as numeric devices [50].

Figure 17. Variant hand stencils, central Queensland, Australia (courtesy C. Sefton).

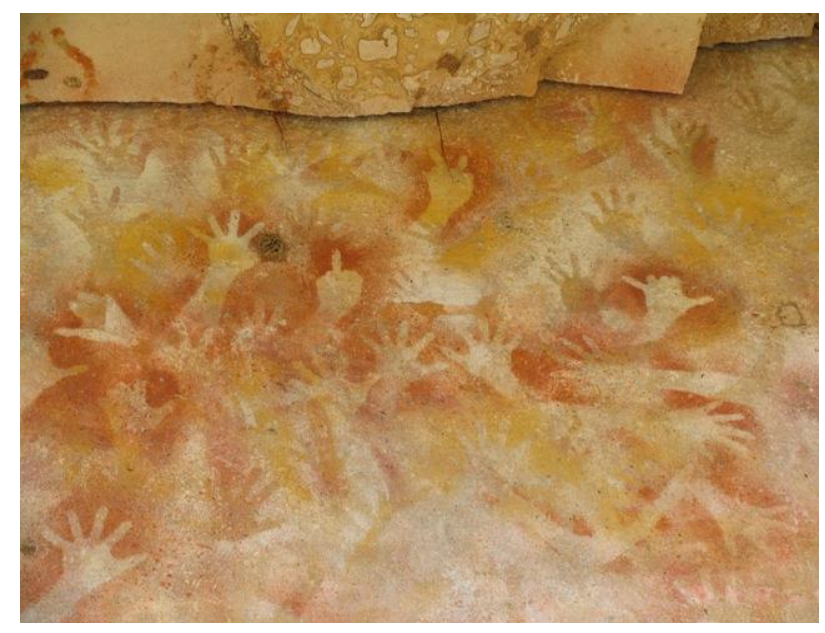

Figure 18. Illustration of possible stencil image and signal gesture matches from G. L. Walsh, “Mutilated Hands or Signal Stencils?” Australian Archaeology 1979, 9, p. 35.

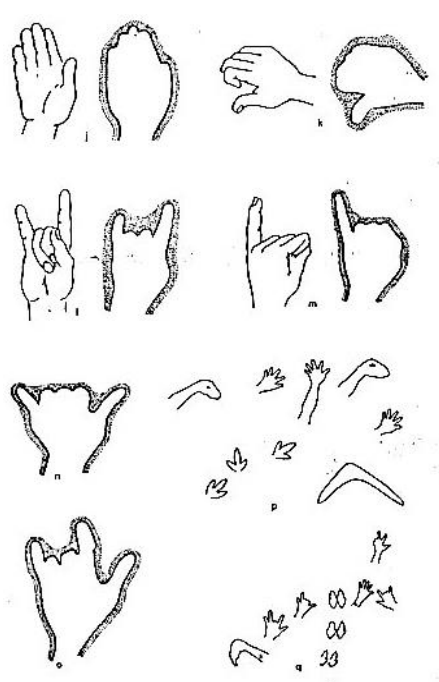




\subsection{A Resolution to the Debate?}

While new perspectives were entering the debate in Australia, in France Barrière-who on the question of the way stencils are made, endorses the spitting pigment from the mouth hypothesis ("the simplest way . . . is to fill the mouth with coloured liquid, then blow it out while pursing the lips slightly", [23], p. 76) —was taking up the Cartailhac-inspired position of his colleague Sahly by arguing that variant hands at Gargas are a result of the reduction of fingers to "stumps" through injury, disease or pathological deformity. Sahly had recorded a total of 24 examples of missing joints and identified several finger stump types- "pointed, squared off and spatulate", something which on the bent finger theory could in fact be explained by affine perspectival effects. In these quarters the view remained entrenched, however, that it would have been "physiologically impossible" to achieve a number of the hand shapes recorded at Gargas by bending fingers. Here the voices of Barrière and his collaborator on the book, Sahly, are in emphatic agreement: "The hands are in fact mutilated ..." ("Les mutilations existent . . ." ([23], pp. 78-83). The two take exactly the same stand as Malvesin-Fabre et al. who had insisted that "les mutilations de Gargas sont réelles, et non pas simulées" ("Gargas mutilations are real, not simulated": [22], p. 12). This view is reiterated as late as the 1990s: "les doigts sont amputés et non pliés" ("Fingers are amputated, not folded": [51], p. 54).

Against all this, however, Clottes and Courtin, in their review of the "mutilated hands" debate centred on Gargas, point out that the investigations of Leroi-Gourhan and Lorblanchet, and in particular the "very methodical research" of Groenen, show conclusively that it is possible to replicate all the variations through finger-folding strategies ([47], p. 69). The rediscovery in 1985 of the submerged cave of "Cosquer" on the French Mediterranean should have put an end to the pathology thesis, and what Clottes and Courtin have had to say in this regard is compelling:

In fact, if this hypothesis were accurate, one would have to assume that two groups of people, living more than 250 miles from one another in different environments, contracted the same rare disease at about the same time and reacted to it in the same way, that is, by immortalizing their amputations on cave walls using identical techniques ([47], p. 67; see also [52], p. 115).

Notwithstanding these conclusions, the mutilation thesis continues to circulate: witness the following statement provided by Walsh on Australia's Kimberley Foundation website featuring Kimberley region art:

There are numerous apparently "mutilated" hands, with "missing" elements ranging from joints of a single digit to several digits, at times including the thumb. Similar occurrences were recorded in the ancient stencils of underground caves in the Gargas region of the French Pyrenes [sic]. These are genuine "amputations" [italics mine], unlike many of the deliberately folded finger forms used to create the "signal" stencils [53].

Nevertheless Walsh's claim that, "unlike many of the folded finger forms used to create the 'signal stencils' of central Queensland", many variant hand stencils in the Kimberley are "genuine" images of hands missing digital segments, still needs testing for plausibility along the lines of a Groenen replication experiment, since the pictorial examples provided are inconclusive ([54], p. 115; [11]). 


\subsection{Complicating Matters: The Question of the Hand's Palm-to-Surface Application}

Mathews, who had witnessed the making of both positive and negative hands, was sure that "in both these methods, it was the palm, and never the back of the hand, which was used" ([43], p. 148). Because the hand is the tool in stencilling, the question of whether palms or backs of hands are used is a technical issue. The notion that backs of hands might have been applied to a surface may have originated as part of the debate about mutilation, since it has been suggested that it would be easier to produce variant hands in this way. Barrière/Sahly counter the idea of a hand "with fingers bent placed upwards against the rock" by producing examples whose awkward locations preclude this explanation. ([23], pp. 78-83). Barrière and Sueres reaffirm this position, opposing what they regard as the contrary and difficult to maintain "inversion" theory of Leroi-Gourhan. They argue that the inclusion of a fist, and even a forearm, as part of an image implies palmar application - otherwise production would involve impossible gymnastics. To clinch the matter, they provide a special case (Gargas, Panel 7, hand 2) to illustrate the force of their argument that, without "une inversion acrobatique", dorsal application would produce a wrist oriented to the right, whereas the stencil in question is oriented to the left, as would naturally happen with palm-to-surface ([51], p. 50). Equally conclusively, and with respect to Cosquer Cave, Clottes and Courtin argue that "the topography of the walls and ceilings most often allows us to dismiss the hypothesis of such a procedure" ([47], p. 70).

\section{Future Research Avenues}

When we approach rock art from a technical standpoint we focus on the opportunities of the human organism embedded in its environment to engage in specific goal-directed behaviours in which the affordances of the material world are meaningfully utilized. For a long time now researchers have entertained the view that stencils and prints belong to a special category. Significantly what sets them apart from painted, drawn, pecked or abraded images is that the body itself is employed as direct tool. In "The case for hand stencils and prints as proprio-performative" [3], I sought to tease out some of the implications of this distinctive feature of hand-marking - in the process distinguishing it from the related technique of finger-fluting on the grounds of the automatic quasi-representational particularizing character of stencils and prints. By focussing on the "ecological self" in action and the iconic trace of an action which remains after a hand is stencilled or impressed, I set out-appealing to the twin notions of perceived movement in performative images and an evoked mirror neuron response- to demonstrate that hand-marking opens up immediate possibilities for communication.

Tacit support for my argument is near at hand. When it was decided to form the International Federation of Rock Art Associations (IFRAO) at the 1988 meeting of the Australian Rock Art Research Association (AURA) a number of decisions were made. One of them was to accept the Consens proposal that the hand image should be adopted as IFRAO's logo ([55], p. 175) on the grounds that it is found around the world. What was intuitively understood was the hand mark's transparent primary meaning of direct address, maker to receiver. The stock hand-stencil or print is all that is needed for such an address. But with embellishment through decoration or patterning or, alternatively, manipulating fingers to vary the iconic hand image, a foundation is laid for elaborated communication in the form of symboling. 
For those wishing to throw more light on the significance of hand marks I suggest the following research goals:

(1) Further dating

(2) A map of variant hand sites around the world

(3) Targeted studies of indicators for saliva in pigment

(4) Further comparative study of gestural signs and "incomplete" hands

(5) Re-examination of the ethnographic sources used by Walsh [44] and Wright [49]

(6) Salvage ethnography relating to extant sign languages world-wide (see for example The iltyem-iltyem "sign language" project focussed on Central Australian groups, [56].

\section{Conclusions}

In conclusion to this discussion of largely technical matters, it is important to stress that an exclusivist approach centred on procedure alone is likely to overlook important factors determining the way an image is made. When it comes to understanding what we encounter in the field, ethnography remains an invaluable resource. As Huntley et al. remind us: "choices regarding every aspect of rock art production, from pigment procurement, placement, application, and motif form are culturally mediated choices" ([24], p. 93). At the same time, however, we should appreciate that our ethnographic sources relating to the cultural aspects of hand-marking belong to recent time, the period of contact. All things considered - and notwithstanding the value we will put on ethnography where it happens to exist - it is only with a vivid sense of apparently unbridgeable distance from origins that we may think of recovering, through extant mythologies and rituals, memetic vestiges of our dialogic beginnings - those faint remembrances which might serve to throw light on the ur-act of symbolic communication.

When attempting to understand first impulses, our prime preoccupation will need to be the situation of the ecological human self in an environmental niche which offers material affordances for the appearance of readable marks of presence. Only by focussing in the first instance on the biological, rather than the cultural, will we begin to understand how the nearest thing to casual but nevertheless propitious marks - when recognised, repeated and varied - may become the stuff of an adaptable system of exograms, viz an organisable external arrangement of remembered signs promoting an entirely new freedom of mental activity.

\section{Acknowledgments}

I am indebted to the staff and invaluable resources of the Australian Institute of Aboriginal and Torres Strait Islander Studies (AIATSIS) library, Canberra, Australian Capital Territory.

\section{Conflicts of Interest}

The author declares no conflict of interest. 


\section{References}

1. Neisser, U. (Ed.) The Perceived Self: Ecological and Interpersonal Sources of Self-Knowledge; Cambridge University Press: Cambridge, UK, 1993.

2. Gibson, J.J. The Ecological Approach to Visual Perception; Houghlin Mifflin: Boston, MA, USA, 1979.

3. Dobrez, P. The case for hand stencils and prints as proprio-performative. Arts 2013, 2, 273-327, doi:10.3390/arts2040273.

4. Taçon, P.; Langley, M.; May, S.K.; Lamilami, R.; Brennan, W.; Guse, D. Ancient bird stencils discovered in Arnhem Land, Northern Territory, Australia. Antiquity 2010, 84, 416-427.

5. Walsh, G.L. Managing the Archaeological Sites of the Sandstone Belt; Central Queensland Aboriginal Corporation for Cultural Activities and Queensland National Parks and Wildlife Service: Rockhampton, Australia, 1984.

6. Lorblanchet, M. Spitting Images: Replicating the Spotted Horses of Pech-Merle. Archaeology 1991, 44, 24-31.

7. Lorblanchet, M. Art Pariétal: Grottes Ornées du Quercy; Ėditions du Rouergue: Rodez, France, 2010.

8. Bednarik, R.G.; Achrati, A.; Tang, H.; Muzzolini, A.; Dimitriadis, G.; Seglie, D.; Coimbra, F.; Sher, Y.A.; Consens, M. Rock Art Glossary: A Multilingual Dictionary, Expanded Second Ed.; Australian Rock Art Research Association: Melbourne, Australia, 2010.

9. McCarthy, F. Australian Aboriginal Rock Art; Australian Museum: Sydney, Australia, 1967.

10. Durham University. Ongoing Research Projects: Hand Stencils in Upper Palaeolithic Cave Art. Available online: https://www.dur.ac.uk/archaeology/research/projects/all/ (accessed on 6 September 2014).

11. Groenen, M. Les représentations de mains negatives dans les grottes de Gargas et de Tibaran (Hautes-Pyrénées): Approche méthodologique. Bulletin Societé royale belge d'Anthropologie et de Préhistoire 1988, 99, 81-113.

12. Le Quellec, J.-L.; de Flers, P. Peintres et Gravures d'avant les Phaerons du Sahara au Nil; Fayard/Soleb: Paris, France, 2005.

13. Pike, A.W.G.; Hoffmann, D.L.; Garcia-Diez, M.; Pettitt, P.B.; Alcolea, J.; de Balbin, R.; González-Sainz, C.; de las Heras, C.; Lasheras, J.A.; Montes, R.; et al. U-Series dating of paleolithic art in 11 Caves in Spain. Science 2012, 336, 1409-1413.

14. Aubert, M.; Brumm, A.; Ramli, M.; Sutikna, T.; Saptomo, E.W.; Hakim, B.; Morwood, M.J.; van den Bergh, G.D.; Kinsley, L.; Dosseto, A.; et al. Pleistocene cave art from Sulawesi, Indonesia. Nature 2014, 514, 223-227, doi:10.1038/nature13422.

15. Australian National University. Types of Rock Art. Available online: http://rsh.anu.edu.au/rockart/ index.php/types-of-australian-rock-art (accessed on 5 February 2014).

16. Spencer, B.; Gillen, F.J. The Native Tribes of Central Australia; Macmillan and Co., Ltd.: New York, NY, USA, 1899. Available online: https://archive.org/details/nativetribesofce00spenuoft (accessed on 21 October 2014).

17. Basedow, H. Knights of the Boomerang: Episodes from a Life Spent Among the Native Tribes of Australia; Hesperian Press: Carlisle, Western Australia, 2004. 
18. Zogbaum, H. Changing Skin Colour in Australia: Herbert Basedow and the Black Caucasian, Including Herbert Basedow's Knights of the Boomerang and David Kaus's Essay "On the Photography of Herbert Basedow"; Australian Scholarly Publishing: North Melbourne, Australia, 2010.

19. Taylor, L. Seeing the Inside: Bark Painting in Western Arnhem Land; Oxford Studies in Social and Cultural Anthropology; Oxford University Press: Oxford, UK, 1996.

20. Brandl, E.J. Australian Aboriginal Paintings in Western and Central Arnhem Land: Temporal Sequences and Elements of Style in Cadell River and Deaf Adder Creek Art; Australian Institute of Aboriginal Studies: Canberra. Australia, 1973.

21. Bradshaw Foundation. Bradshaw Foundation World Rock Art; Hand Paintings. Available online: http://www.bradshawfoundation.com/hands/ (accessed on 5 February 2014).

22. Malvesin-Fabre, G.; Nougier, L.R.; Robert, R. Gargas: La Terre et L'Homme; Édouard Privat: Toulouse, France, 1954.

23. Barrière, C. L'art Parietal de la Grotte de Gargas; Palaeolithic Art in the Grotte de Gargas; Part 1, BAR; Supplemenary Series 14; Drapkin, W.A., Translator; British Archaeological Reports: Oxford, UK, 1976.

24. Huntley, J.; Watchman, A.; Dibden, J. Characteristics of pigment art sequence: Woronora Plateau, New South Wales. Rock Art Res. 2011, 28, 85-97.

25. Gunn, R.G. Hand sizes in rock art: Interpreting the measurements of hand stencils and prints. Rock Art Res. 2006, 23, 97-112.

26. Mulvaney, K. What to do on a rainy day. Rock Art Res. 1996, 13, 3-20.

27. McNickle, H. Reply to comments and an update on the Victoria River District. Rock Art Res. 1993, 10, 38-40.

28. Walsh, G.L. Bradshaws: Ancient Rock Paintings of North-West Australia; Edition Limitée for The Bradshaw Foundation: Geneva, Switzerland, 1994.

29. Chaloupka, G. Journey in Time, the World's Longest Continuing Art Tradition; William Heinemann Australia: Chatswood, Australia, 1993.

30. Gunn, R.G. Patterned hand prints: A unique form from Central Australia. Rock Art Res. 1998, 15, 75-80.

31. Bednarik, R.G. Rock Art Science: the Scientific Study of Palaeolart; Aryan Books International: New Delhi, India, 2007.

32. Elkin, A.P. Cave paintings in the Carnarvon Ranges, South-East Queensland. Oceania 1940, 11, 114-115.

33. Huntley, J. Taphonomy or paint recipe: In situ portable X-ray fluorescence analysis of two anthropomorphic motifs from the Woronora plateau, New South Wales; Aust. Archaeol. 2012, 75, 78-94.

34. Ward, I.; Watchman, A.; Cole, N.; Morwood, M. Identification of minerals in pigments from Aboriginal rock art in the Laura and Kimberley regions, Australia. Rock Art Res. 2001, 18, 15-23.

35. Cole, N.; Watchman, A. Blue paints in prehistory: Preliminary investigations into the colour blue in Aboriginal rock paintings at Laura, Cape York Peninsula. Rock Art Res. 1993, 10, 58-61. 
36. Wainwright, I.N.M.; Helwig, K.; Rolandi, D.S.; Gradin, C.; Podestá, M.M.; Onetto, M.; Achero, C.A. Rock Paintings Conservation and Pigment Analysis at Cueva de las Manos and Cerro de los Indios, Santa Cruz (Patagonia). In Proceedings of the ICOM Committee for Conservation, 13th Triennial Meeting, Rio de Janeiro, Brazil, 22-27 September 2002; Vontobel, R., Ed.; James and James (Science Publishers): London, UK, 2002; pp. 582-589.

37. Cole, N.; Watchman, A. Painting with plants: Investigating fibres in Aboriginal rock paintings at Laura, north Queensland. Rock Art Res. 1992, 9, 27-36.

38. Elkin, A.P. The Australian Aborigines; Angus and Robertson: Sydney, Australia, 1974.

39. Berndt, R.M. Love Songs of Arnhem Land; Thomas Nelson: Melbourne, Australia, 1976.

40. Watson, C. Piercing the Ground, Balgo Women's Image Making and Relationship to Country; Freemantle Arts Centre Press: Freemantle, Western Australia, 2003.

41. Leroi-Gourhan, A. Gesture and Speech; White, R., Translator; The MIT Press: Cambridge, MA, USA, 1993.

42. Gunn, R.G. Mulka's Cave Aboriginal rock art site: Its context and content. Rec. West. Aust. Mus. 2006, 23, 19-41.

43. Mathews, R.H. The rock paintings and carvings of the Australian Aborigines. J. Anthropol. Inst. G. B. Irel. 1896, 25, 145-163.

44. Walsh, G.L. Mutilated hands or stencil s signals? A consideration of irregular hand stencils from central Queensland. Aust. Archaeol. 1979, 9, 33-41.

45. Leroi-Gourhan, A. Les Mains de Gargas. Essai pour une étude d'ensemble. Bulletin de la Société préhistorique française Études et travaux 1967, 64, 107-122.

46. Sollas, W.J. Ancient Hunters and Their Modern Representatives; Macmillan and Co., Ltd.: London, UK, 1911.

47. Clottes, J.; Courtin, J. The Cave Beneath the Sea, Paleolithic Images at Cosquer; Garner, M., Translator; Harry N. Abrams: New York, USA, 1996.

48. Roth, W.E. Ethnological Studies among the North-West-Central Queensland Aborigines; Government Printer: Brisbane, Australia, 1897.

49. Wright, B. The significance of hand motif variations in the stencilled art of the Australian Aborigines, and Comments. Rock Art Res. 1985, 2, 3-19.

50. Overmann, K.A. Finger-counting in the Upper Palaeolithic. Rock Art Res. 2014, 31, 63-79.

51. Barrière, C.; Sueres, M. Les mains de Gargas. Les Dossiers d'Archéologie 1993, 178, 46-55.

52. Clottes, J. The "Three Cs": Fresh avenues towards European Palaeolithic art. In The Archaeology of Rock-Art; Chippindale, C., Taçon, P., Eds.; Cambridge University Press: Cambridge, UK, 1998; pp. 112-129.

53. Kimberley Foundation Australia. Irregular-Infill-Animal-Period: Stencils. Available online: http://www.kimberleyfoundation.org.au/irregular-infill-animal/ (accessed on 21 October 2014).

54. Walsh, G.L. Bradshaw Art of the Kimberley; Tararakka Nowan Kas Publications: Toowong, Australia, 2000.

55. Bednarik, R.G. IFRAO Report: International Federation of Rock Art Organizations Formed. Rock Art Res. 1988, 5, 174-175. 
56. Iltyem.-iltyem: Sign language in Central Australi. Available online: http://iltyemiltyem.com/sign/ (accessed on 4 September 2014).

(C) 2014 by the author; licensee MDPI, Basel, Switzerland. This article is an open access article distributed under the terms and conditions of the Creative Commons Attribution license (http://creativecommons.org/licenses/by/4.0/). 